\title{
O CORPO ABERTO DA MUSA
}

\author{
George França \\ Doutorando em Literatura - UFSC/CAPES
}

\begin{abstract}
RESUMO
Este texto discute o conceito e as implicações da figura da musa no pensamento do filósofo francês Jean-Luc Nancy, com base, especialmente, no livro Les muses, de 1994. A obra em questão reúne uma série de ensaios e conferências escritos ou proferidos em momentos distintos, nas quais o autor tenta articular sua concepção de mundo e comunidade com um pensar a linguagem de maneira diferente da filosofia tradicional (isto é, tendo de lidar com seus limites e com os limites da racionalidade ocidental sem no entanto poder fugir a eles). Trata-se, portanto, de uma discussão a respeito do retorno de uma imagem na contemporaneidade (a da musa), e da teoria que a partir daí se desenvolve sobre a multiplicidade das artes, a estética, o corpo e a ideia de abertura.
\end{abstract}

\section{PALAVRAS-CHAVE:}

Jean-Luc Nancy; filosofia; estética; imagem.

\section{MUSE'S OPEN BODY}

\begin{abstract}
This text discuss the concept and the implications of the muses' image in Jean-Luc Nancy's philosophy, based, specially, in Les muses, a book published by him in 1994. This book is a collection of essays and conferences written or pronounced in different moments, in which the philosopher tries to articulate his conceptions of world and community with a way to think about language differently from the traditional philosophy (having to deal with its limits and with the occidental rationality's limits, without the possibility of abolish them). It's a discussion about the return of an image in the contemporaneity (the muse's image), and about the theory that Nancy develops about the multiplicity of the arts, the aesthetics, the body and the idea of opening.
\end{abstract}

\section{KEYWORDS:}

Jean-Luc Nancy; philosophy; aesthetics; image. 
"Nunca teria acreditado que - sim, acredito com prazer. Histórias, histórias. Não soube contá-las. Não saberia contar esta aqui."

(Jacques Moran, Molloy, Samuel Beckett)

Lanço os pontos e os dados de uma escrita que se sabe de antemão impossível e que insiste em se fazer justamente por sua impossibilidade de se fechar. Insisto com(tra) ela, ela com(tra) mim, ela sem mesmo poder ser ela própria, por não ser uma questão de si, de em si, de consigo ou de conseguir. Não se quer tratado; se assim se quisesse, sua falência seria ainda maior (e são as falências mensuráveis?) do que a que já traz inscrita em si por não poder dizer, por estar fadada a apenas passar. Por outro lado, não é questão de se lamentar um tratado que teria um dia sido possível e que por algum percalço do caminho da humanidade (?) se tornou inviável. Sua impossibilidade esteve sempre em si: hoje (e várias vezes ontem) é que podemos vê-la e assumi-la, sem fechar, procurando, justamente, uma abertura que não é fixa, tão pouco fixável quanto a posição de um elétron: o que persegue essa escrita são pontos em uma orbital, ou nem isso, a orbital como massa, mesmo, como potência e como lugar (em que não resta senão o lugar).

Ao se ensaiar uma fala sobre o pensamento de um contemporâneo como JeanLuc Nancy (e o uso de contemporaneidade não se atém simplesmente ao fato de que ainda esteja vivo e producente na França, lecionando em Strasbourg), surge imediatamente um impasse não exclusivo, mas necessariamente implicado no exercício: qual a possibilidade da linguagem de dizer alguma coisa sem que o que não se diz seja mais forte do que o que se afirma? Ou ainda, se, com o próprio Nancy, admitirmos que o sentido é a existência, como tentar uma armação em algo tão falho (mas de que ao mesmo tempo não podemos prescindir nem para olhar) como a linguagem? Por outro lado, se a pensarmos não mais como insuficiência, mas como puro dispêndio em cuja condição está inscrito o que escapa, o deixar espectro, a relação a ser desenvolvida com ela é a de puro excesso, no sentido de não formar comunidade no sentido de como-um, mas de com-um (a sintaxe antes da semântica). Se falo em uma escrita excessiva, chocante justamente com a ideia ou a possibilidade de uma meta, permeada pela passagem, ou feita ela mesma de permeio, não posso negligenciar a forma como o 
próprio Bataille (ou Pierre Angélique, pseudônimo que adota para publicar o texto Madame Edwarda, nome em que se casam o peso da pedra e a travessia à imaterialidade luminosa de um anjo, não necessariamente bondoso) tratou a relação entre o (de)pensar e o excesso: "O que significa a verdade fora da representação do excesso, se não vemos o que excede a possibilidade de ver, o que é intolerável ver, como no êxtase é intolerável gozar? se não pensamos o que excede a possibilidade de pensar...?" E mais adiante, em nota: "o excesso excede o fundamento: o excesso é aquilo mesmo pelo qual o ser é, de imediato, antes de todas as coisas, fora de todos os limites. O ser talvez se encontre também entre limites: esses limites nos permitem falar (falo também, mas ao falar não esqueço que a palavra me escapa e de mim escapará)."1

Trata-se também (e novamente) da questão do com, de evitar o uso do ser como tal na medida em que este acaba privilegiando uma entidade fechada. Todavia, a problemática que se erige em contrapartida é justamente a de não erigir esse com, nas formas do com-tato, do com-tágio ou em que outras combinações o paradigma permitir, em outra entidade autotélica aglomerativa, ou ainda, em outro ser fechado em si e que se pensa aberto meramente por ser agregador. Isso pressupõe uma mudança na relação com o sentido (não inaugurada, certamente, por Nancy; é necessário levar em conta especialmente não só o papel de $\mathrm{Nietzsche}^{2}$, que chega à formulação de que o próprio fato se dá em linguagem, mas também reflexões como as de Roland Barthes, o qual assinala o declínio da primazia da autoridade do autor sobre uma obra, que, em se desobrar, se faz texto ${ }^{3}$, ou ainda, de Gilles Deleuze e do rizoma, desenvolvido não só

\footnotetext{
1 BATAILlE, Georges. Madame Edwarda. Trad. Osvaldo Fontes Filho. Outra travessia. N. 5. Florianópolis: UFSC, 2. sem. 2005, p. 96-97.

${ }^{2}$ A esse respeito, é possível pensar a própria maneira como Nietzsche define a imagem do andarilho, que caracterizava tão bem a si próprio, como uma possibilidade das derivas do próprio sentido, que só podem se dar em travessias que não determinem metas para fugir da armadilha teleológica: "Quem chegou, ainda que apenas em certa medida, à liberdade de razão, não pode sentir-se sobre a Terra senão como um andarilho - embora não como viajante em direção a um alvo último: pois este não há. Mas bem que ele quer ver e ter os olhos abertos para tudo o que propriamente se passa no mundo; por isso não pode prender seu coração com demasiada firmeza a nada de singular; tem de haver nele próprio algo de errante, que encontra sua alegria na mudança e na transitoriedade." (NIETZSCHE, Friedrich. Humano, demasiado humano. In: _. Os pensadores. Seleção dos textos de Gérard Lebrun; trad. e notas de Rubens Rodrigues Torres Filho. São Paulo: Nova Cultural, s/d.) Essa afirmativa ganharia uma formulação ainda mais sintética, ao final da obra do filósofo alemão, no Crepúsculo dos ídolos, em uma frase como "ser em si mesmo o eterno prazer do vir-a-ser". (NIETZSCHE, Friedrich. Crepúsculo dos ídolos. Trad. Paulo César de Souza. São Paulo: Companhia das Letras, 2006, p. 107.)

${ }^{3}$ E essa crise traz para o bojo da literatura e da escritura o próprio problema da morte: “desde o momento em que um fato é contado, para fins intransitivos, e não para agir diretamente sobre o real, quer dizer, finalmente fora de qualquer função que não seja o próprio exercício do símbolo, produz-se este desfasamento, a voz perde a sua origem, o autor entra na sua própria morte, a escrita começa." (BARTHES, Roland. A morte do autor. In: Ver, também, o ensaio que o segue, Da obra ao texto.) O rumor da língua. São Paulo: Martins Fontes, 2004.
} 
em Mil platôs como também em Kafka: por uma literatura menor). E se pelo com e sem poder prescindir da linguagem havemos de pensar um nós, nos resta para essa ideia de comunidade uma abstração dêitica semelhante à que Benveniste fazia para pensar o que seriam as pessoas efetivas do discurso, um shiftness, dêixis pura, marcação vazia, lugar apenas que não resta senão como lugar; apontar. O que pode ser interessante para se pensar um conceito de arte. Mas como "dar" conceito com a linguagem, que é pura imaterialidade, segurada e afiançada por nada (moeda falsa, em Derrida ${ }^{4}$ ), (a)posta em circulação? Justamente potencializando outra modalidade de linguagem, seja em arte, seja em ensaio (entendendo-se a crítica e o pensamento justamente como uma modalidade radical de ficção), qual seja, a do dispêndio, a do excesso, a do puro dom.

Se por um lado reivindico o excesso e o dom, por outro lado, é necessário reconhecer também a afinidade disso com a definição que Derrida dá ao hímen, em sua afinidade com os indecidíveis, elaborada em sua leitura de Mallarmé, ao voltar ao tópico em Posições. Ao desorganizar as oposições binárias ou a própria dialética, os termos que Derrida assim trata não criam, todavia, uma terceira entidade, que responda às outras duas; não há síntese. Da mesma forma, se estamos pondo a linguagem em jogo, em risco, é facultado pensar em sua posição de hímen, na medida em que, na entrevista a Jean-Louis Houdebine e Guy Scapetta, Derrida afirma que

\begin{abstract}
hímen não é nem a confusão nem a distinção, nem a identidade nem a diferença, nem a consumação nem a virgindade, nem o velamento nem o desvelamento, nem o dentro nem o fora etc.; o gramma não é nem um significante nem um significado, nem um signo nem uma coisa, nem uma presença nem uma ausência, nem uma posição nem uma negação etc. ${ }^{5}$
\end{abstract}

A possibilidade de potencialização se daria na transitoriedade, ou ainda, no nemnem, no que se dá quando não se dá: “o hímen (consumação das diferenças) só acontece quando nada acontece realmente, quando há consumação sem violência, ou violência

\footnotetext{
${ }^{4}$ Na leitura que Derrida faz de Baudelaire em Donner (le) temps, não apenas no ponto da exploração da ambivalência do gesto de doar uma moeda sobre cujo valor absoluto nada se pode dizer (sequer se há valor absoluto), vale notar a elaboração dada à noção de "dom" (tema tomado a Marcel Mauss, em seu Essai sur le don) que muito bem pode ser aplicada à linguagem nas reflexões que ora traçamos: "Pour qu'il y ait don, il faut qu'il n'y ait pas de réciprocité, de retour, d'échange, de contre-don ni de dette." (DERRIDA, Jacques. Donner le temps: la fausse monnaie. Paris: Galilée, 1991, p. 25). Paula Glenadel pensaria a leitura de Baudelaire assim: "o ato de dar uma moeda falsa para criar um acontecimento em aberto, funesto ou não (como uma prisão, ou um real enriquecimento), pertence à esfera do dom incondicional, ainda que também possa ser qualificado como um "mal", ao passo que dar dinheiro falso para reduzir o custo da esmola implica que nada tenha sido dado, pois o cálculo seca a fonte incondicional do dom." (GLENADEL, Paula. Derrida e os poetas: de margens e marcas. In: GLENADEL, Paula; NASCIMENTO, Evando (orgs.). Em torno de Jacques Derrida. Rio de Janeiro: 7Letras, 2000, p. 198.) Ou seja, Glenadel lendo o Baudelaire de Derrida preza justamente o valor do acontecimento, e deste em sua possibilidade do aberto, ou seja, de explodir em significação, de criar indecidibilidade: nada mais próximo de literatura, ou da vida como literatura.

${ }^{5}$ DERRIDA, Jacques. Posições. Trad. Tomaz Tadeu da Silva. Belo Horizonte: Autêntica, 2001.
} 
sem golpe, ou golpe sem marca [...], quando o véu é rasgado sem o ser, quando se faz alguém morrer ou gozar de tanto rir." ${ }^{, 6}$ É curioso notar, por outro lado, que o riso, no texto já citado de Bataille sobre Madame Edwarda, é justamente um sintoma da interdição estabelecida sobre o erótico: "De fato, é o riso que justifica uma forma de condenação desonrosa. O riso nos engaja na via onde o princípio de uma interdição, de decências necessárias, inevitáveis, transmuda-se em hipocrisia cerrada, em incompreensão do que está em jogo."7

E se aposto na linguagem justamente como essa possibilidade de jogo, juntamente com Nancy, a experiência de lidar com ela seria a de, no exercício do pensamento, afirmar a possibilidade de criar um comum não-partitivo, não-representativo, mas a-presentativo. Para isso é fundamental levar em conta o papel do "a" em Nancy, exponencial, por exemplo, no diálogo que estabelece com Lacan em $L$ 'il-y-a du rapport sexuel. Se a linguagem é pensada, aqui, com ele, justamente no que tem de intransitivamente transitiva no sentido de que sempre transita a mas não pode estabelecer uma meta sob pena de elaborar a melancolia da perda do objeto, esse impossível, é preciso que, para debruçarmo-nos sobre o pensamento de Nancy, por mais paradoxal que seja adotar um pressuposto, possamos (nós, que também somos mera marcação, não sujeitos plenos) considerar o deslizamento do sentido não melancolicamente, como excrescência, mas como constitutivo, como passagem.

A questão que se coloca seria, portanto, pensar o lugar da arte (ou a arte como lugar radical e aberto, ou radicalmente aberto) e da literatura no pensamento de Nancy, programa que seria deveras extenso e trairia de antemão o problema do tratado já posto. É, por conseguinte e por coerência com o pensamento do próprio filósofo, necessário pensar no provisório como lugar da arte (que não vem de lugar nenhum e não vai a lugar nenhum, está sempre passando, é (r)event(ural)). É nesse sentido que, tendo em vista elaborar um pensamento radicado dentro do paradoxo já imposto pela maneira como expus o entendimento da linguagem do platô onde me ponho, discutirei a maneira como, em Les muses, lançado em francês em 1994, reunindo diversas conferências de Nancy, o autor tenta articular sua concepção de mundo e comunidade (que se desenvolve em outros pontos de sua obra e que já está incipiente até mesmo em L'oubli de la philosophie (1986) e atravessa o imediatamente anterior Le sens du monde, de

\footnotetext{
${ }^{6}$ DERRIDA, Jacques, apud MAJOR, René. Lacan com Derrida. Trad. Fernanda Abreu. Rio de Janeiro: Civilização Brasileira, 2002, p. 205.

${ }^{7}$ BATAILLE, Georges, Madame Edwarda, op. cit., p. 95.
} 
1993) com um pensar a linguagem de maneira diferente da filosofia tradicional (isto é, tendo de lidar com seus limites e com os limites da racionalidade ocidental sem no entanto poder fugir a eles - ou com o excesso ao limite, a-lógica batailleana). Nesse movimento, é interessante notar como seu pensamento dialoga e contrasta com o Agamben de La comunità che viene (2001), o qual investe justamente no "ser tal que, seja como for, importa", ou seja, na possibilidade de uma comunidade em que no qualquer se dê a singularidade, irredutível a qualquer universal e em que o amor se dá como impossibilidade justamente na incapacidade de uma relação de apreensão sempre permeada pelo fetiche. Lições blanchotianas à parte, pois há em ambos uma preocupação do a venir, mesmo que seja ele da ordem do impossível, Nancy está interessado em uma experiência do corpus como abertura que ainda deseja ou elabora o laço, ainda que tente pensá-lo para além da linguagem como possibilidade de contrato, em algo que poderia beirar a utopia da estesia, do "sentido" levado ao seu paroxismo, mas que, na ideia de ser singular-plural, pode ser aproximado do que Bataille chamaria de "comunidade dos sem-comunidade".. Entretanto, é notório que o filósofo não mais entifica sujeito e objeto para pensar relações de determinação de um corpo sobre o outro, ou ainda, esses corpos como entidades autônomas; é justamente a ideia de limite, de próprio e de impróprio, que é posta aí em crise, de maneira tão vital quanto o risco que se corre em um transplante de coração (operação a que ele, indivíduo, se sujeitou).

Como se se desse a reinventar Ovídio, em pleno 1957, André Malraux lança La metamorphose des dieux, livro que, diferentemente da narrativa dos mitos amarrada por uma transformação elaborada pelo poeta romano, acaba por pensar as próprias imagens, ou o que resta de ruína desse mundo, em seu movimento de devir, de transformação incessante. De fato, seu passeio por entre as "máscaras mortuárias" (ou os restos, o que ainda foi possível apreender) de um mundo perdido assinala justamente a constituição de uma galeria que, à maneira do que postula em seu Le musée imaginaire (cuja primeira versão data de 1947), inventa a arte de um determinado período a partir da mudança de relação com o objeto. Digo da mesma forma que um museu, pois, de acordo com Malraux, é a criação do museu, esse pátio das musas que fica de frente para a praça de sacrifício revolucionário, pátio que também é constituído pelo puro acaso dos achados e dos deslocamentos do que poderíamos chamar de vestígios (palavra a que, veremos, Nancy dá um significado todo especial), que cria uma outra relação com os objetos e assinala um novo patamar da arte. É pensando esses deuses em metamorfose, 
essas pedras que um dia foram objeto de culto e ora se oferecem ao olho de um observador como "arte grega" (o gentílico é fortuito, dado o fato de que nos dirigimos às musas) que Malraux dá o passo além e assinala o papel da poesia (essa filha de uma musa, Érato) na separação entre o mundo mítico-sagrado e o "presente":

La poésie grecque est d'abord séparée de celles de l'Inde, de Babylone et d'Israël par le monde dont elle témoigne; et si l'oeuvre d'Homère appartient à son proprie génie, le monde d'Homère appartient à la mémoire dont il est né, à celle qui l'a transmis: il est élu par la Grèce entière. La poésie oratoire et chantée, liée a la danse, exprime le monde successeur du sacré, fait surgir la geste des dieux des mythes qui la précédaient, la garde de se dégrader em contes; et tout art grec est poésie. Il n'appartenait pas à celle-ci de 'donner leurs noms' aux dieux du sacré; mais c'est elle qui assure le triomphe des Olympiens sur la confusion crépusculaire de leurs prédecesseurs. Ces dieux changeants qui n'ont d'autre constance que celle de leur éclat, nés avec la terre sinon avec l'homme, ne sont pas 'la cause' du divin, ils em sont les figures: le sentiment du divin, comme celui du sacré, est um sentiment fondamental. ${ }^{8}$

É interessante, frente a essas considerações, notar certa afinidade entre a poesia e a ideia de "criar mundos", não apenas no sentido mais estrito em que a tradição ocidental pensou essa possibilidade, ou seja, na separação entre o que seria o "ficcional" e o "real", uma vez que se entende que o acesso que um indivíduo tem ao Real é sempre um efeito de sentido, e, portanto, ficção. Nesse sentido, mesmo que o que esteja em jogo em Malraux seja um princípio de separação (ou de individuação, como o papel que Nietzsche atribui a Apolo em $O$ nascimento da tragédia) entre o mundo dos deuses, que habitaria o imaginário dos gregos, e o de então, em que os deuses não mais podiam ser vistos andando pela face da terra. De qualquer forma, estamos perto de Nancy ao pensarmos a poesia (fundamentalmente como arte ligada à memória, esse tão importante operador na construção do sentido) como potência de linguagem e criação de mundos, dado que o mundo não é uno, se dá no singular-plural da disseminação de sentidos. Mais: se toda a arte grega pode ser definida como poesia, e se a poiesis caracteriza-se justamente por um "fazer", nada mais justo do que dizer que a matriz das musas, umas contra as outras, e regidas não só pela mãe, Mnemosine, a memória, mas também pela mão de Érato, a musa da poesia. Uma questão a se pensar, perseguindo esse fio, seria o deslocamento da noção do "fazer" para a "abertura", que ressalta o peso não mais da técnica na definição do artístico, mas da deliberação e do gesto do artista para uma abertura.

\footnotetext{
${ }^{8}$ MALRAUX, André. La metamorphose des dieux. Paris: Nouvelle Revue Française / La Galerie de la Pléiade, 1957, p. 58.
} 
Mas retrocedo ainda um (ou mais de um) passo. Em pleno século XIX, quando, por um lado, Champollion já começava a decifrar pela pedra de Roseta os primeiros hieróglifos e o mundo se via às voltas com o enigma egípcio, outro francês se via às voltas com sistematizar a mitologia grega e romana em um exercício historiográfico não solitário. Trata-se de Pierre Comelin, autor do até hoje lido e relido Mythologie grecque et romaine, espécie pedagógica de manual sistematizador dos mitos greco-romanos. $\mathrm{O}$ movimento não é solitário: é notável que a figura da musa poderia ser lida como uma dessas sobrevivências de que falava Aby Warburg quando formulou o conceito de Nachleben, vida póstuma e em metamorfose das obras de arte e das formas culturais. Assim como essas formas não estagnam, e, tensionadas por forças, transformam-se, lêlas em um movimento que leve em conta o tempo como dimensão do eterno retorno (à Nietzsche) implica um trabalho que poderia ser pensado como necromancia: "sobreviven en el Archivo las voces de los difuntos, y la piedad del historiador tiene el poder de volver a conferir um timbre a las voces inaudibles, si no desdeña la fadiga de reconstruir la unidad natural de la palabra y de la imagen."9 Trata-se de dar voz ao morto, mas o morto, como cadáver em retorno, volta diferido, justamente por aquele que lhe dá voz fora da repetição estéril do espetáculo.

Pierre Comelin observa, em seu tratado de mitologia, que as Musas, segundo Hesíodo, são nove. Clio, palavra que vem da mesma raiz de Glória, designa a musa da escrita da história (visão que se afasta da história como catástrofe professada por Walter Benjamin, por exemplo, em Sobre o conceito de história); coroada de louros, traz um trompete e um livro nas mãos e é envolvida pelo tempo. Poder-se-ia lê-la como se manifestasse que não há saída para a história, ou ainda, que não haveria como estar fora do tempo, que abraça todos os lugares e todos os escritos, o que contrasta com a tarefa da crítica anacrônica: "Time is a tiranny to be abolished", era o que afirmava o grupo de transition (1927-1938), revista fundada por Eugéne Jolas, em que foi publicado, significaticamente, o Finnegan's Wake de James Joyce. A Euterpe cabia a música, e, segundo Comelin, os elementos que a circundavam seriam uma maneira de os antigos expressarem "combien les lettres ont de charme pour ceux qui le cultivent"10. A Thalia

\footnotetext{
${ }^{9}$ WARBURG, Aby. Arte del retrato y burguesia florentina. Domenico Ghirlandaio en la Santa Trinita. Los retratos de Lorenzo de Medici y de sus familiares (1902). In: BURUCÚA, José Emílio (org.). Historia de las imágenes e historia de las ideas. Trad. José Emílio Burucúa, Andrés Jáuregui, Laura Malosetti y Gabriela Siracusano. Buenos Aires: Centro Editor de América Latina, s/d, p. 21.

10 COMELIN, Pierre. Mythologie grecque et romaine. Disponível em: $<$ http://gallica.bnf.fr/ark:/12148/bpt

6k25485.image.r=mythologie + grecque.f105.tableDesMatieres.langPT $>$. Acesso em 15 jan. 2010.
} 
cabia a Comédia. O nome da musa deriva, segundo o mesmo autor, do verbo equivalente a "florir", etimologia que nos permite visualizar uma proximidade entre a poesia, esta que tem a flor por metáfora clássica, e o teatro; mais ainda, com o texto dramático que Aristóteles julgaria como "menor". Melpômene, cujo nome deriva de "cantar", sua contraparte, apresenta aspecto circunspecto e vem seguida, como seria a lição aristotélica, pelo Terror e pela Piedade. A dança ${ }^{11}$, essa que rodopia, é regida por Terpsícore, que seria, também, mãe das Sereias (donas do canto de fatal atração, ou seja, estaria ela própria entrelaçada ao canto, e a este em sua manifestação mais fatal ${ }^{12}$; adiante, com Bataille, teremos notícia da conexão entre erotismo, literatura e morte). A lírica é reservada ao domínio de Érato, palavra cuja origem Comelin identifica a Eros (e ao erótico, por conseguinte). A musa carrega, ainda, a lira em uma mão e o arco em outra. A Polímnia estaria reservado o domínio da Retórica e das "artes" da persuasão com a palavra (e é notável como, nessa imbricação dos domínios das musas, nos aproximamos da poesia como fundamento de todas as artes, tal como defendia o já citado Malraux). Urânia (do grego Ouranos, céu) presidia a Astronomia e aparecia

\footnotetext{
${ }^{11}$ É propício lembrar, a respeito da dança e de sua aproximação com o tempo e o espaço, portanto, com a imagem e a poesia, que também são atravessadas por essas dimensões, o comentário que Susana Scramim faz a respeito de uma conferência proferida por Giorgio Agamben: "Me recordo bem de sua conferência, na qual Agamben afirmava, relembrando um dos primeiros tópicos que elege para ler e refletir sobre a vida póstuma das imagens em Aby Warburg e fundamentado na definição de dança de um teórico da dança da metade do século XV, Domenico da Piacenza, em seu Della arte di ballare et danzare, que o flamenco era um balé que não tinha um lugar para acontecer, pois que era uma iminência carregada de tempo. Giorgio Agamben começou sua conferência sobre o flamenco com um comentário de Ramon Gaya sobre a bailarina Pastora Imperio, 'esto todavía no era baile sino creación del lugar donde el baile deberia ocurrir', reunindo, dessa forma, algumas reflexões preliminares para compor sua leitura da dança como uma relação entre tempo e espaço a qual não dá origem a um movimento nem tem expressão no corpo, mas que encontra no tempo a sua essência." (SCRAMIM, Susana. A exceção e o excesso. Outra travessia. N. 5. Florianópolis: UFSC, 2. sem. 2005, p. 172.) O trabalho da arte, como evento, seria, portanto, o de criar espaços, o de inventar lugares que por si só não existem, e que não restam senão como lugares, sempre cambiáveis e provisórios. Vale lembrar que a discussão do ensaio de Scramim destina-se justamente à maneira como a idéia de exceção procura inscrever na lógica da soberania (e portanto no poder) justamente aquilo que poderia se dar como excesso, (não-)lugar do que põe a lógica fora de si, arte como potência.

${ }^{12}$ Ana Cristina Cesar, ao retornar a Mallarmé em Nada, esta espuma, escreve: "da amurada deste barco / quero tanto os seios da sereia." A experiência da amurada, do limiar, desencadeia, na leitura de Raúl Antelo, o que seria uma poesia pós-eventural, atravessada pela necessidade de afrontar-se com o desejo, encarando a poesia, essa sereia, como "potência equívoca da ficção, a transformação do texto em hipótese esquiva e semovente. [...] O poema quer o particular concreto, 'os seios da sereia'. E muda em conseqüência o lugar da poesia, não mais na proa mas na popa. Ou antes, não no último lugar, o que, extremando a análise, inverteria e reinventaria a escatologia cristã mas no penúltimo, na murada. O poeta pós-eventural desdenha o limite e opta pelo limiar porque o limite é último ao passo que o limiar, penúltimo. O limiar busca sair dessa série e começar outra. Aspira à continuidade deslocada. O limite, porém, condensa totalidade e reincide no mesmo lugar." (ANTELO, Raúl. Nada que o sol não explique. Inimigo Rumor. N. 4. Rio de Janeiro: Sette Letras, abr. 1998, p. 92.) O poema em questão refere, ainda, uma deusa (por que não pensar em uma musa, uma vez que elas estariam sempre tão perto dos poetas) sobre cuja ação o próprio eu-lírico não sabe afirmar se emerge, dando-se a ver, na superfície, ao contato (entre peles), ou se apenas se manifesta como uivo, voz sem linguagem que tortura, que faz vibrar com, que se oferece $\dot{A}$ escuta (tradução para o título de outro livro de Nancy).
} 
medindo o mundo; é notável, ainda, que a primeira face de Vênus, filha de Urano, é justamente chamada Vênus Urânia, como aparece nos escritos de Basilius Von Ramdohr (1798) $)^{13}$. Por fim, Calíope é a de "belo rosto", musa da poesia heróica, e, coroada de ouro, teria, segundo Hesíodo, primazia sobre as outras musas (e eis, novamente, o lugar de destaque dado à poesia na tradição grega); segundo Comelin, alguns atribuem a ela, também, a maternidade de Orfeu. Ou seja: já na rainha das musas a arte teria incorporado sua dimensão órfica, dilacerada, de canto descendente aos infernos. Seria, talvez, a porta de entrada para o Mal, reivindicado por Bataille.

É, por um lado, sintomático que se escreva ainda sobre a maneira mítica de se ver as musas, as inspiradoras das artes, entidades extracorpóreas ao "artista" que dariam o sopro da execução de sua arte, mesmo quando o Romantismo já havia muito bem disseminado a noção do gênio ou do indivíduo exponencialmente talentoso e diferenciado da multidão como verdadeiro artista, agenda que desembocaria na figura heróica do artista de vanguarda, esse homem que, mesmo se pondo fora da massa, fabrica o que considera ser o "biscoito fino" que por ela ainda deve ser comido, ou ainda, que projeta suas concepções e a de seu grupo na conformação de ideários modernos de nação ou de ação. Talvez não por outra razão Nancy tenha se preocupado, em Les muses, em dedicar um "capítulo"14 a medir-se (ou acertar as contas) com Hegel, paladino de uma visão autonômico-progressista-evolutiva da história, do tempo e da arte. Em Hegel manifesta-se a sucessão da musa pela donzela, não apenas, mas justamente um dos problemas que está intimamente ligado a toda a filosofia de Nancy: o fim. Seu pensamento, com efeito, é da ordem de uma finitude-infinita, ou de uma infinitude-finita: atenta sempre para o que confina, para o fim não mais como limite, mas como limiar, como na leitura de Raul Antelo anteriormente citada. Para Nancy, entretanto, seria consenso que a postulação de um "fim da arte" em Hegel seria o fim de uma "religião estética", ou ainda, da arte como lugar de aparição do divino. É facultado pensar com Bataille, em suas apreciações sobre o mal, justamente sobre esse colapso de uma dimensão redentora ou salvadora na arte, que, assim, estaria liberada para dizer de

\footnotetext{
${ }^{13}$ É notável, ainda, a possibilidade de vincular Terpsícore e Urânia se pensarmos que é na órbita que um astro dança, rodando em torno de si e em torno de outro astro. A versão moderna desse mito, contando com o hasard das assonâncias, poderia ser o dançarino astro maior que sobe paredes: Fred Astaire. (Agradeço a indicação a Evandro de Sousa, que também dança.)

${ }^{14}$ Uso a palavra na falta de melhor terminologia; ainda que se apresente como um livro, Les muses é uma reunião de textos apresentados em diferentes ocasiões, os quais, para Nancy, revelam algum tipo de afinidade (eletiva) temática.
} 
tudo, para além da lei moral (ou ainda, em uma opção menos libertária, criando outras morais), como se pode ver em sua leitura de Emily Brönte em La littérature et le mal:

Le plus remarquable dans ce mouvement est qu'um tel enseignement ne s'adresse pas, comme celui du christianisme - ou celui de la religion antique -, à une collectivité ordonnée dont il serait devenu le fondement. Il s'adresseà l'individu, isolé et perdu, auquel il ne donne rien que dans l'instant: il est seulement littérature. C'est la littérature, libre et inorganique, qui en est la voie. De ce fait, il est moins que l'enseignement de la sagesse païenne ou de l'Église, amené à composer avec la nécessité sociale, représentée souvent par des conventions (par des abus), mais aussi par la raison. Seule la littérature pouvait mettre à nu le jeu de la transgression de la loi - sans laquelle la loi n'aurait pas de fin - indépendamment d'un ordre à créer. [...] La littérature est même, comme la transgression de la loi morale, un danger.

Étant inorganique, elle est irresponsable. Rien ne repose sur elle. Elle peut tout dire. ${ }^{15}$

Por outro lado, é a partir desse pensamento do fim que Nancy se confronta com a possibilidade de dissolução de todas as artes em poesia (e mesmo o imbricamento entre as musas, já na mitologia clássica, aponta para a possibilidade desse fim, fim que não é retorno à prosa, como quereria o Agamben de $O$ fim do poema, fim que acaba atravessando a escrita filosófica do próprio Nancy) como um fim que seria a "posta em perigo" $" 16$. De qualquer forma, em sua preocupação com o corpo, com o sensível, com o toque, Nancy teme a perda da ligação entre a arte e o sensível, perigo maior que vê para ler a afirmação de Hegel. A poesia seria, nesse sentido, uma possibilidade-limite, ou quiçá a abertura de um limiar, uma vez que a linguagem é assinalada, nessa leitura de Hegel, como possível tendência a reduzir ao signo inerte o sensível da arte. Entretanto, está dado um grande impasse: como pode o humano prescindir da linguagem em sua relação com a coisa, se essa linguagem, em sua intransparência, é constitutiva do ser humano, do olhar e da relação com o mundo? Se, por um lado, "El punto de disolución del arte es entonces esencialmente idéntico al punto de reafirmación de su independencia plástica, y de la afirmación correlativa e igualmente esencial de la pluralidad intrínseca de los momentos de esa plasticidad sensible" ${ }^{, 17}$, por outro, para Nancy, a poesia se enfrenta com a prosa do pensamento. Restaria, pois, numa tarefa de transformar o pensamento em alegria de criar, transformar o pensamento (esse que Hegel assimila à prosa, que, a seu ver, seria uma "não-arte") em uma instância poética, capaz de criar, de recuperar sua vinculação com o corpo e o sensível para sair da ordem da significação, fechada, como a trata Nancy desde L'oubli de la philosophie, para reencontrar-se com o sentido, essa abertura para a criação de mundos. Nesse sentido,

\footnotetext{
${ }^{15}$ BATAILLE, Georges. La littérature et le mal. Paris: Gallimard, 1957, p. 25-26.

${ }^{16}$ NANCY, Jean-Luc. Las musas. Trad. Horácio Pons. Buenos Aires: Amorrortu, 2008, p. 64.

${ }^{17}$ Ibid., p. 65.
} 
pois, a arte poderia se reencarnar no limite mesmo de sua dissolução, no pensamento, que sai da ordem do especulativo (ao pé da letra, aquele que espelha, que procura reproduzir um objeto) para adentrar o imaginativo, que produz o novo justamente como imagem, como aproximação do radicalmente distante, tal como proporia Nietzsche em A Gaia Ciência ${ }^{18}$.

Um livro que se propõe a levar as musas em seu nome deve ser lido sob a clave de uma reinscrição da ideia de mito na contemporaneidade: ora, por que tornar a pensar com essas figuras retornantes que rondam o Ocidente desde os gregos? Ou ainda: com que mitos contrastá-las hoje? O que resta do mito, o que se faz mito, que mito é possível? É interessante, nesse ponto, por um lado, pensar justamente as sobrevivências de uma concepção de arte que precede mesmo à idéia de musa, e que se manifesta não só em Nancy, como em Bataille (muito lido pelo filósofo de Strasbourg), em suas leituras de Lascaux, como, por outro lado, no pensamento de que a modernidade também inventou suas mitologias, assunto tão bem explorado por Roland Barthes, bem como no fato de que, se quisermos desfazer a primazia da racionalidade centrada ocidental, não nos resta senão assumirmos que tudo quanto dizemos sobre o mundo (ou mesmo a maneira como a ele podemos ter acesso) é rasgadamente ficção, e, nesse sentido, máquina mitológica.

As Musas de Nancy são imagens de vetores de pluralização, em princípio, no caso das artes, e, por conseguinte, dos mundos, uma vez que a tarefa do pensamento é, sempre, a de criar mundos, singulares-plurais como os corpora. A palavra "musa" traz no bojo de seu étimo uma tensão, ou seja, uma força que se revela como indecidível, que mantém a lira tesa, ou ainda, que a propulsiona para o movimento e a multiplicidade: "La Musa anima, levanta, excita, pone en marcha. Vela con fuerza sobre la forma." ${ }^{19}$ Nesse sentido, é visível que o filósofo está prezando um problema que se coloca, para além do poeta inspirado que recebe de uma divindade sua arte, um

\footnotetext{
${ }^{18}$ E eis que esse livro de Nietzsche também termina não pela prosa, mas pela poesia, depois que o filósofo, furibundo com a repetição estéril das coisas no mundo, conclama: "Minha gaita de foles já está pronta, e também minha garganta - ela pode soar um pouco rouca, paciência! estamos nas montanhas. Mas o que ouvirão é algo novo; e se não o compreendem, se entendem mal o cantor, que importa isso? É a 'maldição do cantor'. Mais claramente poderão ouvir sua música e seu modo de tocar, e ao som de sua flauta poderão também melhor - dançar. É o que querem?...” (NIETZSCHE, Friedrich. A Gaia Ciência. Trad. Paulo César de Souza. São Paulo: Companhia das Letras, 2001, p. 288.)

${ }^{19}$ Ibid., p. 11.
} 
problema que se manifesta em vários pontos dos manifestos de diferentes vanguardas, e mesmo antes disso: podemos pensar, aqui, na premente relação do Futurismo com a velocidade, o movimento e a deformação (vide os experimentos fotográficos dos irmãos Bragaglia nos anos 10, reunidos em Fotodinamismo futurista, ou ainda, os manifestos de Marinetti, o primeiro dos quais data de 1909), ou, mesmo antes disso, a maneira como o Expressionismo se relaciona com uma matriz barroca que pensa a potência das forças da arte, tão prezada que foi por Walter Benjamin em A origem do drama barroco alemão. É importante, ainda, notar que a força, em Nancy, não é pensada unilateralmente: não se trata de apenas um ponto de tensão, mas de pluralidade, do mesmo plural como princípio com o qual se constituiria uma ideia de comunidade inoperante no pensamento do filósofo: o singular-plural.

Nancy se pergunta pelas razões da existência de várias artes, e não de apenas uma, muito mais do que com pensar se a prática artística é fruto de inspiração ou transpiração, binômio explorado, por exemplo, por Octavio Paz no capítulo Inspiração de $O$ arco e a lira, com predileção pelo trabalho formal (ainda que admita que pela inspiração é possível voltar ao Ser, no sentido que dá ao uso do termo por Heidegger), ou ainda, no clássico Filosofia da composição, de Edgar Allan Poe, que procura ratificar em termos praticamente calculistas a escritura de um poema, retirando-o do domínio das clássicas "musas". Na outra mão, os experimentos com automatismos de escrita propalados pelos surrealistas, que nem sempre resultaram tão "automáticos" ou "gratuitos".

Parênteses posto, resta analisar como o filósofo francês procura pelo que chama "singular plural das artes", tendo, primeiramente, de se confrontar com Adorno e suas oscilações entre a consideração de uma tensão entre particular e universal no que diz respeito à existência de uma Arte e das artes. $\mathrm{O}$ impasse em não conseguir lidar com a singularidade, a demanda normativa pela vanguarda e uma visão autonômica fazem com que o projeto de Adorno diste do de Nancy, ao ler a arte.

\begin{abstract}
Assim como as artes enquanto tais não desaparecem na arte sem deixar vestígios, assim também os gêneros e as formas em cada arte particular. Sem dúvida, a tragédia ática era também a cristalização de um universal bem como a reconciliação do mito. A grande arte autônoma surgiu em acordo com a emancipação do espírito e, não mais do que este, sem o elemento do universal. Porém, o principium individuationis que implica a exigência do esteticamente particular não é apenas, por seu turno, universal enquanto princípio, mas inerente ao sujeito que se emancipa. ${ }^{20}$
\end{abstract}

\footnotetext{
${ }^{20}$ ADORNO, Theodor. Teoria estética. Trad. Artur Morão. São Paulo: Martins Fontes, 1982, p. 226.
} 
Nancy chega a recuperar Adorno em seu movimento para tratar da pluralidade das artes, mas não se trata, em seu pensamento, de pensar que as artes dividiram-se em particulares a partir de um grande universal, ou que há uma categoria universal que subsuma os particulares de cada "tipo" de manifestação artística. Por outro lado, Nancy toma a Adorno justamente essa idéia de que não há como as artes desaparecerem sob o rótulo de uma arte sem deixarem pegadas, ou seja, há sempre um vestígio, conceito, aliás, definitivo do próprio campo artístico nos escritos do próprio Nancy, especialmente em Les muses. Se Adorno, por um lado, chega a mencionar a constelação (palavra muito cara a seu amigo Benjamin), ainda não consegue abandonar um pensamento universalizante, que separa uma grande arte autônoma de uma outra, dada como pequena, a qual participaria do plano de emancipação do sujeito, que, além de ser considerado de um ponto de vista que o dá como plenamente consciente de si (ou com essa possibilidade, que a Psicanálise afirma impossível), teria a possibilidade de ser livre a partir de um "esclarecimento" de natureza diversa do iluminista, detratado por Adorno e Horkheimer na Dialética do esclarecimento.

Se para Nancy, com efeito, da arte não resta senão um vestígio, ou se é justamente a evanescência, a efemeridade e a ideia de marca que podem ser pensadas como definitivas em um tempo no qual, segundo a formulação que dá Raúl Antelo ao problema, não se trata mais de perguntar o que é o belo, mas de inquirir a todo o tempo o que é a arte (graças, por exemplo, ao impasse da impossibilidade da poesia - pautada ainda numa estética kantiana - após Auschwitz, ou ainda, aos gestos de Duchamp que puseram a noção do artista como maker em colapso, apontando que a arte reside justamente em construir lugar - ou assinar, dar firma, apontar). Com efeito, assimilando arte e vestígio, marca, imagem, impronta, Nancy afirmará que "el arte em su totalidad no manifiesta mejor su naturaleza o su meta cuando se convierte en vestígio de si mismo: cuando, apartado de la grandeza de las obras que crean mundos, parece pasado y ya no mostra más que su pasaje. ${ }^{21}$ Para Nancy, portanto, conta, menos do que a obra, a passagem, a travessia, o trânsito, em uma noção de tempo que o entende, herdando de Nietzsche, como eterno retorno, uma vez que está sempre passando, e que interessa muito menos o objeto do que a marca, o movimento, o atravessamento que queda em aberto.

\footnotetext{
${ }^{21}$ NANCY, Jean-Luc, Las musas, op. cit., p. 113.
} 
Por outro lado, é notável que esse ensaio também volta a Hegel (assim como o segundo do livro) para pensar que, se este afirma que "el arte es la presentación sensible de la Idea", lembra que a noção de Idéia em Hegel está ligada não à intelecção, mas à reunião em si e para si das determinações do ser, ou, em outra formulação, "la presentación a si del ser o la cosa. Es, de tal modo, su conformación y su visibilidad interna, y también la cosa misma en cuanto es vista, palabra que debe tomarse a la vez como sustantivo (la cosa como uma forma visible) y como adjetivo (la cosa vista, aprehendida em su forma, pero a partir de sí o de su esencia)." ${ }^{22}$ Em suma, poder-se-ia entender essa proposição como se o campo da arte, o domínio das musas, fosse a possibilidade de uma visibilidade sensível de uma visibilidade inteligível, ou ainda, uma manifestação do ser da forma e da forma de ser, ou, em suma, a visibilidade do invisível, "el sentido sensible del sentido absoluto", entendendo-se, aí, a duplicidade entre o sentido como relação com o corpo e o sentido, em oposição à significação, como abertura. Se, por um lado, é justamente esse o trunfo e a potência da arte, o fato de que, perpassada pela efemeridade, termina por apresentar seu próprio conceito, um conceito vazio, por outro,

que el sentido sea su propria retirada, eso es, talvez, lo que nos queda de la Filosofía de la Idea; es decir, eso es lo que nos queda por pensar. Pero el hecho de que la retirada del sentido no sea otra vez una Idea impresentable que debe presentarse es lo que hace de ese resto, y del pensar indisociablemente ligado a él, uma tarea del arte; pues si la retirada no es una idealidad invisible que debe visualizarse, es porque se traza en su totalidad directamente em lo visible, como lo visible mismo (o como lo sensible en general). ${ }^{23}$

Trata-se, portanto, de encontrar no pensamento um veio que consiga lidar com o irrepresentável, a abjeção, o horror, o excesso, o que sobra, o rastro, o que não se inscreve: seria, pois, uma maneira de encontrar o pas au-delà entre o Real e a arte, ou ainda, a possibilidade bífida de um passo além quando não há transcendência, não há um para-além? Por outro lado, se não resta essência e se o espaço da arte é o do resto, do excesso, resta saber por que, em todo seu percurso filosófico insistindo em uma noção do fora, do ex-istir, do ex-ceder, Nancy não se permitiu, como Georges Bataille, tocar o ex-cremento.

Criteriosamente, todavia, Nancy distingue imagem de vestígio em arte. $\mathrm{O}$ vestígio, essa espécie de "cuerpo extraño, difícil de identificar, entre presencia y ausencia, todo y nada, imagen y Idea, y esquivo con respecto a estos pares dialéticos", é

\footnotetext{
22 Ibid., p. 121.

${ }^{23}$ Ibid., p. 125.
} 
um conceito que demanda o retorno do filósofo ao pensamento teológico (movimento muitas vezes operado por Agamben, também), ou, mais precisamente, ao conceito de vestigium:

el vestigium Dei está directamente en el campo sensible, es lo sensible mismo en su ser creado. El hombre es imago en cuanto rationalis, pero el vestigium es sensible. Y con ello se dice, por lo demás, que lo sensible es el elemento en el cual, o a la manera del cual, la imagen se borra y se retira. La Idea se pierde en ello, y deja su huella, claro está, pero no como la impronta de su forma: como el trazado, el paso, de su desaparición misma. ${ }^{24}$

$\mathrm{O}$ vestígio diria respeito, portanto, menos à racionalidade do que ao sensível, ao domínio de onde a intelecção e a identificação se retiram, restando apenas como marcas de um trânsito. É necessário entender que, ainda que o vestigium seja a raiz que dá nascimento a palavras como "investigação", não se trata, no trato com ele, de uma "busca", o que nos levaria à teleologia de um objeto determinado ou de um fim que pudesse encerrar o sentido da relação. Trata-se, por outro lado, de seguir as pegadas pôr o passo no rastro de outros passos. Além disso, assim como é negada uma origem inequívoca para o próprio (vocábulo) vestigium, que não resta senão como marca e sintoma de que ali houve uma passagem, de que no tempo e no espaço algo se deu, é necessário notar que toda vez que Nancy fala de pas ouve-se tanto "passo" quanto "não", ou seja, a lição blanchotiana está aí inscrita. Se, por um lado, Blanchot demandava o passo além mesmo ciente de que não havia para-além, ou seja, no âmbito de um pensamento de imanência absoluta, por outro, é na noção de uma arte que caminha para seu desaparecimento que o pensamento de ambos acaba novamente confluindo. Blanchot, em O livro por vir, entende que a literatura caminha em direção a si mesma, o que quer dizer em direção ao seu desaparecimento, apaixonada por questionar a si própria e por se mostrar como campo em que, apagando a possibilidade do limite, dá-se a possibilidade do impossível, da dispersão ${ }^{25}$.

Adiante, Nancy ainda definirá o vestígio como "el resto de um paso"; novamente inscrita aí está a ambivalência entre o "passo" e o "não" (ainda que estejamos citando a partir da tradução ao espanhol, é notável a palavra traduzida nesse contexto). E sendo um passo, uma pegada, é também ligada, de alguma forma, ao pé: "La planta del pie nos introduce en el orden de lo llano y lo de plano, la extensión horizontal sin referencia a la vertical tendida." ${ }^{26}$ A referência aí recai novamente sobre Bataille, que no texto $O$

\footnotetext{
${ }^{24}$ Ibid., p. 129.

${ }^{25}$ BLANCHOT, Maurice. O livro por vir. Trad. Maria Regina Louro. Lisboa: Relógio D’água, 1984.

${ }^{26}$ NANCY, Jean-Luc, Las musas, op. cit., p. 130.
} 
dedão do pé, publicado na revista Documents, debatendo contra a primazia da cabeça (entendida como comando, como racionalidade centrada) ou das mãos (prezadas como os órgãos que permitem ao homem confeccionar objetos e, ainda, escrever) na cultura ocidental, propõe que o pé seria a parte mais humana do corpo do homem, uma vez que, muito menos do que ser útil para os deslocamentos, é ele quem propicia ao homem aquilo de que ele mais se orgulha: a postura ereta ${ }^{27}$. O pé, portanto, é o que levanta o corpo, que não tem sentido, mas $f a z$ sentido: é o pé que deixa esses vestígios, esses restos de passos; é com os pés que se dança, que se impulsiona o trânsito; o pé, como aquele que deixa pegadas, não faz ruínas, verticais, presenças, mas deixa suas marcas sem verticalidade, sem profundidade, sem essência; a marca do pé é pura retirada, é afirmação negante e negação afirmante. E não seria gratuito assimilar a marca de uma pegada a outras, produzidas voluntariamente nas paredes das grutas, com o sopro contra as mãos, pelas quais também se interessaria Bataille em Lascaux ${ }^{28}$.

E é essa pintura que Nancy mapeia como sendo a manifestação em que se mostra a surpresa e a estranheza do homem diante de sua própria humanidade, ou ainda, de seu aparecer a si como um estranho. Entretanto, esse estranho, a um só tempo, é

\footnotetext{
${ }^{27}$ BATAILLE, Georges. Le gros orteil. In: BATAILLE, Georges. Oeuvres complètes. V. I. Paris: Gallimard, 2001, p. 200.

${ }^{28}$ Vale notar que até mesmo um modernista brasileiro muito menos interessado por questões estritamente ligadas ao primitivismo, como Murilo Mendes, não pôde deixar, já nos anos 50 do século XX, de se debruçar, ao traçar seu panorama do Espaço espanhol, de se voltar para Altamira, outro conjunto arqueológico que fascinou os europeus preocupados em perquirir as origens do homem durante aquele século. Murilo, além de considerar que Altamira revela a antigüidade do homem moderno (mais do que a do próprio primitivo, lido como jovem; "infante", talvez), retoma de Ortega y Gasset a idéia de que a descoberta dos indícios na Espanha teria funcionado como uma espécie de dispositivo hipermnésico para o homem, pois teria triplicado o horizonte da memória humana, da história e da civilização. Mais do que isso: a "magia" emanada das pinturas das cavernas de Altamira seria, para Murilo Mendes, significativa de um limiar entre o homem o animal, de uma relação de "ódio-simpatia" entre ambos, como "cúmplices de terror". Por um lado, o primitivo aparece como possibilidade de resgate de uma dimensão do mágico, em arte, talvez perdida (ou mudada) em função da reprodutibilidade e do desenvolvimento da técnica, mapeadas que foram por Walter Benjamin no já clássico ensaio de 1936; por outro, o desejo da destruição e a possibilidade de compartilhar o pathos em sua dimensão além da linguagem é que aparecem como perdidos dentro da arca de Altamira. Seu valor seria de ordem "universal" justamente por preceder a história; talvez pudesse se pensar que precede a própria linguagem (se se pode pensar o humano sem ela, constitutiva que é). Por outro lado, onde termina a imagem e começa a linguagem? Há limite possível traçável entre ambos? Ou estaria ali em Altamira uma possibilidade da origem cravada na linguagem, na imagem, no homem como aquele que imagina? Murilo Mendes diria que "As pinturas plantam ainda o problema da mimesis: onde termina para o pintor da caverna a fronteira entre realidade e imaginação? Seria ele um estilista, ou um simples copiador da realidade? Pintaria de memória, longe dos animais arquétipos; teria já construído seu arquivo de imagens? Quero crer que sim.” (MENDES, Murilo. Altamira. In: __ Poesia completa e prosa. Org. Luciana Stegagno Picchio. Rio de Janeiro: Nova Aguillar, 1994, p. 1121.) Ou seja: o trabalho de artista começaria a partir do momento em que o homem pode dispor das imagens como de um arquivo, palavra que, como já apontado, vem plena de implicações teóricas, mas fundamentalmente, implica muito mais disponibilidade e possibilidade de recombinação do que hierarquia e valor; muito menos determinação inequívoca de uma verdade genética do que possibilidade de proliferação da imagem como potência.
} 
reconhecível: é, talvez, o primeiro momento em que o homem se defronta com o outro de si que o habita, com o que não domina. Talvez seja lícito dizer que, na produção dessa imagem, Nancy percebe, ao afirmar que "Reconozco em ello que soy irreconocible para mí mismo, y sin eso no habría reconocimiento alguno. Reconozco que eso constituye tanto un ser como un no-ser, y que yo soy uno en otro" ${ }^{29}$, que se dá com o movimento de pintura na gruta um primeiro reconhecimento daquilo que Freud, ao ler $O$ homem de areia, de Hoffmann (servindo-se, pois, justamente da arte, da literatura, para elaborar um conceito psicanalítico), chamaria de Unheimlich, ou seja, não apenas o estranho, mas o estranho que vive na casa, que habita o indivíduo, espécie de outro desconhecido a si mesmo que, mesmo devendo permanecer recalcado, se manifesta. Por outro lado, talvez seja legível, aí, justamente o ponto em que o sujeito se mostra não mais pleno e consciente, ou ainda, não mais passível de ser encerrado em uma significação: o que o Murilo Mendes do Pós-poema chamaria de "ser e não ser", o “não sou eu, nem sou outro" de Mário de Sá-Carneiro, o “j’est un autre” de Rimbaud, a "sede de ser outro" de Oswald de Andrade.

Em Nancy, ainda, não é o lugar que abriga a pintura, mas a pintura que inventa o lugar: é o gesto, ou ainda, o vestígio que faz Lascaux ou Altamira serem o que são, e não eles que fazem com que o gesto tenha existido, ou mais, venha a ser lido como arte. Se é certo afirmar, com ele, que mostrar é separar, gerar ausência, portanto, as mãos que foram lidas como o começo da arte são, também elas, a aparição do humano. "En ese sentido, el 'arte' está presente en su totalidad desde el comienzo. Incluso consiste en eso: estar presente en su totalidad en el comienzo. El 'arte' es el comienzo mismo, y atraviesa, como um único gesto inmóvil, los veinticinco mil años del animal mostrans, el animal monstrum. ${ }^{30} \mathrm{O}$ homem, nesse sentido, é o animal que mostra, que aponta, e a quem, se quiser fazer sentido, como abertura, resta apenas o "á́,, dêitico, gruta, como relação possível entre peles para além da linguagem, essa que, mesmo que sempre se esquive, tenta definir. Se esse "aí" é o que dá possibilidade ao "a-pared-cer", em que a parede (mais que a pintura ou que o quadro) revela o quão definitiva é, ou ainda, em que a arte se desvincula do domínio do maker e se exibe como apresentação de presença sem presença, criação de um lugar que não pode restar preenchido para nunca se fechar, é necessário pensar, então, que as mãos pintadas, essas marcas, "no presentan otra cosa que la presentación misma, su gesto abierto, su exhibición, su aperturidad, su

\footnotetext{
${ }^{29}$ NANCY, Jean-Luc, Las musas, op. cit., p. 101.

${ }^{30}$ Ibid., p. 103.
} 
patefacción y su estupefacción." ${ }^{31}$ Esse movimento de abertura, em que importa muito menos o que se vê do que o gesto aberto de mostrar e de gerar campos para além do visível ou do visual, em que importa o movimento para fora, o ex-por, que não deixa, por isso mesmo, de ser (a)posta em pose, ou seja, de algo que nunca o é em si, mas sempre outro, em um trânsito de si-mesmo a si-outro.

Nancy não deixa de notar que as Musas reaparecem em Benjamin como possibilidade de apresentação do ideal do conteúdo puro da arte, justamente devido ao seu ser plural. E se é no plural que se faz sentido, e se o sentido se entende como abertura, entendo que a tarefa contemporânea da arte e do pensamento fica muito distante de explicar, justificar ou reproduzir o mundo, e justamente mais próxima de criar mundos, da delenda esquiva (como a chamava Haroldo de Campos) de disseminar mitos. Entretanto, que mitos nos são possíveis? Que Musas habitam o panteão que os inspira? Não se trata, certamente, dos sistemas fechados de comunicação e mensagem, como Roland Barthes definiu os mitos em Mitologias, que, no que Guy Debord viria a caracterizar em A sociedade do espetáculo, reproduzem-se esterilmente. Trata-se, isso sim, de uma relação com o mundo que justamente não se dê mais no plano da literalidade e do estéril, não demande por significações únicas e procure minar a ordem que se pretende natural para os fatos do mundo. Uma operação de leitura, quer ela se dê em termos de ato crítico ou de fazer artístico (que nunca deixa de ser, também ele, um ato crítico, e político; ou ainda, a possibilidade de não-fazer), se mostra tanto mais potente quanto possa pensar que as musas são as forças que se embatem umas com as outras, não apaziguam e não se fecham em consenso, dando vazão para uma comunidade que não consiste em ser como o outro mas em poder viver com, tocar. Com uma incisão como essa, será possível até mesmo um novo modo de relação com as imagens estéreis do espetáculo, esse fato inilutável, como o caracteriza o Perniola de Enigmas. Não deixa de ser digno de nota que uma consulta à palavra "musa", no buscador Google, traga as mulheres que mais apareceram no carnaval brasileiro, artistas do cenário pop como Lady GaGa ou a proclamação irônica feita sobre mulheres bonitas porém pouco intelectualmente dotadas como Luciana Gimenez. Teria, aí, a fama

\footnotetext{
${ }^{31}$ Ibid., p. 103.
} 
substituído a possibilidade deslizante do mito como ficção, singular-plural? Teria sido reposto o culto? Que gesto é possível diante dessas imagens? E se pensássemos as Musas, no plural, como encarnadas na abertura, na gruta, no olho da mulher que se oferece deitada aos olhos de um voyeur, como aquela que se entrega e a quem aquele que a contata também se entrega, como em Étant donées, de Marcel Duchamp, experiência para além do quadro, de olhar o que não se devia ver e tentar tocar o que está sempre além? Se as musas pudessem todas estar nesse hay, sobre o qual nada é possível afirmar, sob pena de tentar encarcerar o que deve estar sempre aberto? E se as musas, assim como o tempo, forem aquilo que sempre passa?

Se estamos diante do paradoxo da possibilidade desse toque, mas buscamos a abertura, somos, ainda, obrigados a lidar com o vazio de sentido de todo sentido. Talvez ninguém o tenha feito melhor do que Samuel Beckett, seus clochards que nada conseguem fazer (Esperando Godot), seu agente que nada consegue buscar ou narrar (Molloy), seus Dias felizes que nada conseguem senão afogar em quinquilharia. O paradoxo reverbera sobre todas estas linhas: que posso eu narrar que não tente encerrar o sentido de um pensamento que se quer aberto, se o faço em linguagem? Como tocar o pensamento? Não seria na arte que se conquistaria o lugar de maior potência para ativar um pensamento da ordem do não-racionalista, do não-evolutivo? Não seria na possibilidade de não-fazer, com que Beckett define o artista em seus diálogos com Georges Duthuit, que surgiria a possibilidade de uma relação da ordem do aberto com o sentido, uma comunidade de singulares-plurais, em que o vazio ganha o estatuto de coisa e surge a necessidade de lidar com ele?

O aberto tem de ser um lugar que não se autopressuponha, que não trabalhe com o pressuposto, em que o sentido possa se dar como potência. Nesse sentido é preciso pensar a arte em sua eventualidade, em seu caráter de evento, nunca fechado, que nunca se esgota, que sempre retorna de maneira diferida (de si para consigo e diferindo os tempos - caráter do que Barthes chama texto), que nunca se fecha, sempre com-fina. $\mathrm{O}$ gesto é o que sobra como entre(lugar), para além do entendimento metafísico de que o sujeito determina o objeto ou de uma reversão pura e simples em que o objeto passa a ser determinante e se entifique por si só. O gesto, como lugar da abertura, é (meio sem) fim.

É, por fim, curioso notar que do étimo de musa também sai mosaico, colagem de peças absolutamente díspares entre si, que acabam por conformar uma imagem. E no mosaico, potencial singular-plural de peças, que constitui uma revista, na abertura de 
um dos números de Orígenes, o poeta Juan Ramón Jimenez dá a saída para se pensar uma relação novamente encantada com o mundo, que o retire da ordem estéril das univocidades e dissemine sentido, ao dizer que

$$
\begin{aligned}
& \text { La 'claridad' es tan 'mito' como la ninfa, crítico y versificador voluble. } \\
& \text { Todo es mito, y el mito es progreso del hombre, puesto que es 'realidad } \\
& \text { májica', lo máximo conseguible en hombre y poesia. }{ }^{32}
\end{aligned}
$$

A quem soube me entender durante toda a crise que esse colapso do pensamento gesta: mãe, Raúl, Ev., Renata, Luiza, Fernando A., Gabriela, Guilherme, Arthus, Laísa.

\section{REFERÊNCIAS}

ADORNO, Theodor. Teoria estética. Trad. Artur Morão. São Paulo: Martins Fontes, 1982.

ANTELO, Raúl. Nada que o sol não explique. Inimigo Rumor. N. 4. Rio de Janeiro: Sette Letras, abr. 1998.

BATAILLE, Georges. La littérature et le mal. Paris: Gallimard, 1957.

. Oeuvres complètes. V. I. Paris: Gallimard, 2001.

. Madame Edwarda. Trad. Osvaldo Fontes Filho. Outra travessia. N. 5. Florianópolis: UFSC, 2. sem. 2005.

BARTHES, Roland. O rumor da língua. São Paulo: Martins Fontes, 2004.

BECKETT, Samuel. Molloy. Trad. Ana Helena Souza. São Paulo: Globo, 2007.

BLANCHOT, Maurice. O livro por vir. Trad. Maria Regina Louro. Lisboa: Relógio D’água, 1984.

BURUCÚA, José Emílio (org.). Historia de las imágenes e historia de las ideas. Trad. José Emílio Burucúa, Andrés Jáuregui, Laura Malosetti y Gabriela Siracusano. Buenos Aires: Centro Editor de América Latina, s/d.

COMELIN, Pierre. Mythologie grecque et romaine. Disponível em: <http://gallica. bnf.fr/ark:/12148/bpt6k25485.image.r=mythologie+grecque.f105.tableDesMatieres.lang PT>. Acesso em 15 jan. 2010.

DERRIDA, Jacques. Donner le temps: la fausse monnaie. Paris: Galilée, 1991. Posições. Trad. Tomaz Tadeu da Silva. Belo Horizonte: Autêntica, 2001.

\footnotetext{
32 JIMENEZ, Juan Ramón. Encuentros y respuestas. Orígenes. Ano III, n. 10. La Habana, Verano 1946. In: RIVAS, José Manuel de (ed.). Orígenes: Revista de arte y literatura. V. II (n. 7-12). Ciudad de México; Madrid: El Equilibrista; Turner, s/d.
} 
GLENADEL, Paula; NASCIMENTO, Evando (orgs.). Em torno de Jacques Derrida. Rio de Janeiro: 7Letras, 2000.

MAJOR, René. Lacan com Derrida. Trad. Fernanda Abreu. Rio de Janeiro: Civilização Brasileira, 2002.

MALRAUX, André. La metamorphose des dieux. Paris: Nouvelle Revue Française / La Galerie de la Pléiade, 1957.

MENDES, Murilo. Poesia completa e prosa. Org. Luciana Stegagno Picchio. Rio de Janeiro: Nova Aguillar, 1994.

NANCY, Jean-Luc. Corpus. Madrid: Arena, 2003. . El olvido de la filosofia. Madrid: Arena, 2003. . El sentido del mundo. Buenos Aires: La Marca, 2003. . Las musas. Trad. Horácio Pons. Buenos Aires: Amorrortu, 2008.

NIETZSCHE, Friedrich. Os pensadores. Seleção dos textos de Gérard Lebrun; trad. e notas de Rubens Rodrigues Torres Filho. São Paulo: Nova Cultural, s/d.

$\overline{\text { Letras, } 2001 .}$

A Gaia Ciência. Trad. Paulo César de Souza. São Paulo: Companhia das . Crepúsculo dos ídolos. Trad. Paulo César de Souza. São Paulo: Companhia das Letras, 2006.

RIVAS, José Manuel de (ed.). Orígenes: Revista de arte y literatura. V. II (n. 7-12). Ciudad de México; Madrid: El Equilibrista; Turner, s/d.

SCRAMIM, Susana. A exceção e o excesso. Outra travessia. N. 5. Florianópolis: UFSC, 2. sem. 2005. 